\title{
INVESTIGATION ON THE INFLUENCE OF THE CONSTITUENT ELEMENTS IN PMC LAMINATES ON INTER LAMINAR SHEAR STRENGTH (ILSS) AND IMPACT STRENGTH
}

\author{
W. ANDREW NALLAYAN ${ }^{1}$, K. GURUSAMI ${ }^{2} \&$ K. R. VIJAYAKUMAR ${ }^{3}$ \\ ${ }^{1}$ Research Scholar, St. Peters Institute of Higher Education and Research, Chennai, Tamil Nadu, India \\ ${ }^{2}$ Associate Professor, Department of Mechanical Engineering, St. Peters Institute of Higher Education and Research, \\ Chennai, Tamil Nadu, India
}

${ }^{3}$ Professor, Department of Mechanical Engineering, Dr.MGR Educational and Research Institute, Chennai, Tamil Nadu, India

\begin{abstract}
The behavior and response of the laminates under varied modes of loading depends on its constituent elements. The degradation and failure of laminates depends on the responses of the fiber and matrix of the composites.Considering the visco elastic nature of most of the polymer matrix composites, it is imperative to measure the extent of matrix load bearabilty, in particular against shear and impact conditions. While designing and analysis of the laminates that are used for high performance applications, like in Radome, ILSS and impact strength are the two significant properties that are matrix dependent and hence are often measured. Further enhancement of the stiffness of the matrix could be attained by dispersing second phase fillers like, glass spheres and fumed silica. Critical properties that influence the matrix in general viz., ILSS and Impact strength, were investigated under varying material constraints, like fiber diameters, weaving pattern of fibers, Stacking sequences and the number of the plies across the laminates. It was found that unidirectional fibers with higher gsm as used in thin cross plied laminates filled with fillers in the nano regime, found to exhibit better performances than their other counterparts.

KEYWORDS: Fillers, Impact \& ILLS Strength
\end{abstract}

Received: May 07, 2020; Accepted: May 27, 2020; Published: Jun 19, 2020; Paper Id.: IJMPERDAUG202011

\section{INTRODUCTION}

Epoxy blended with Cyanate ester have become a routine utility in making laminates for high performance application which require good structural as well as di electrical properties. These applications basically needs the testing to be done on the samples under varied loading conditions and also under varied sets of material constraints.(6-7) Interply delamination under impact, cracking \& the mechanisms to retard it and ply orientation to delay the fracture are the specific topics often investigated by researchers.(8-10). The inter relation between the various variables on materials, processing, and geometry fronts like hybrid reinforcements, different types of curing methods and a variety of stacking sequence with different orientations besides the micromechanics meant for decelerating the damage causing modes are some of the investigations that are widely researched.(11-12). But, not much was done to relate the role played by fillers in improving ILSS and Impact strength. Hence to enhance these properties, fillers in the micro (glass spheres) and nano (fumed silica) regime are dispersed in the matrix and the 
laminates are compression molded and oven cured. Curing influence the toughening of the matrix by increasing cross link density in the cyanate ester blended epoxy matrix, during polymerization process. Interlaminar shear strength and Impact strength are two vital properties that helps in assessing the versatility of the laminates for structural applications.

By varying the laminate geometry, material and processing constraints, the optimization of the laminated structures can be achieved. Fibers of random, bi directional and unidirectional orientations with different gsms, different ply numbers with cross ply stacking, hand lay and compression moulding procedures using room and oven curing conditions and with choices from fillers are the good number of variables that have been applied.

\section{MATERIALS FABRICATION}

The laminate composites were fabricated from neat epoxy and then from blended resin loaded with $0 \%, 5 \%, 10 \%$ and $15 \%$ of Cyanate ester for the Matrix and E-Glass fibers of types like., random oriented, bi directional and unidirectional fibres with 300,400 and $410 \mathrm{gsm}$ for reinforcements, with an optimized stacking of four plies at (00/900) 2 reinforcement. Specimens were filled with adds on fillers of micro glass microspheres and nano fumed silica by $0 \%, 3 \%, 5 \%, 7 \%, 10 \%, 20 \%$ and $30 \%$ by volume. Also laminates in 2, 3, 4 and 5 plies were fabricated in both room and oven curing conditions to investigate the laminate geometry on the properties. Fabrication options of hand layup and compression moulding were introduced under room and oven curing conditions. A good number of variables were chosen to investigate the inter related factors that could influence the optimized laminate. ASTM guidelines were observed while fabricating and cutting the samples for testing against Impact and ILLS strength.
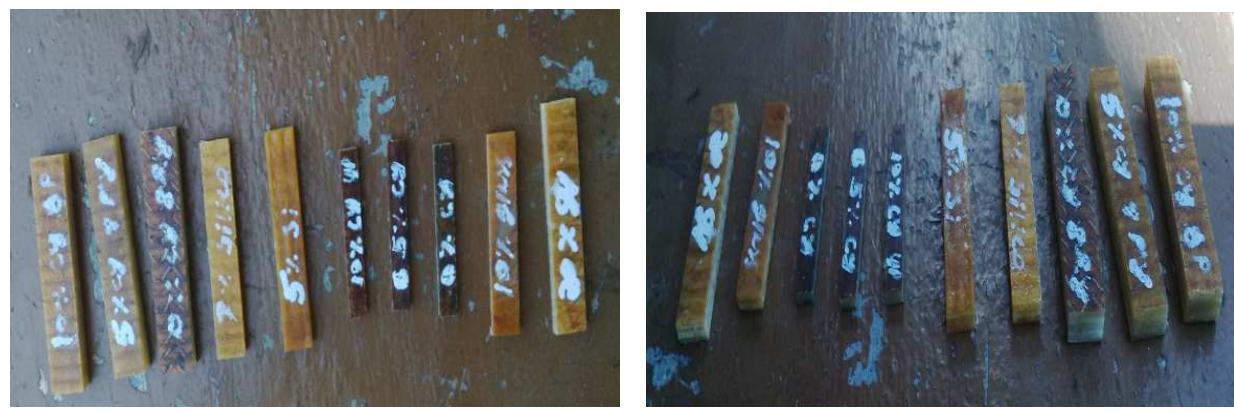

Figure 1: Few Impact Test Specimens.

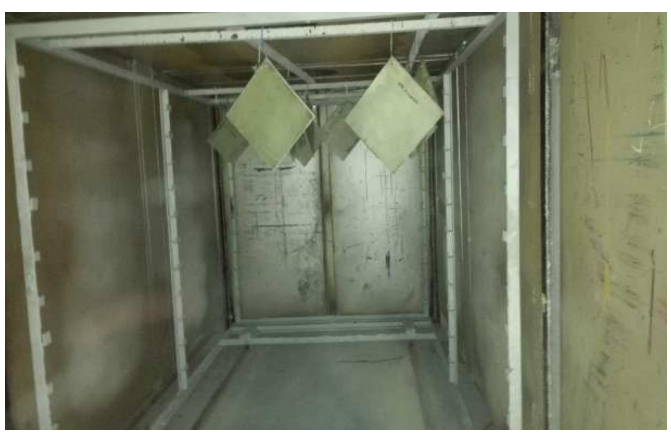

Figure 2: Oven Curing Process of Laminates

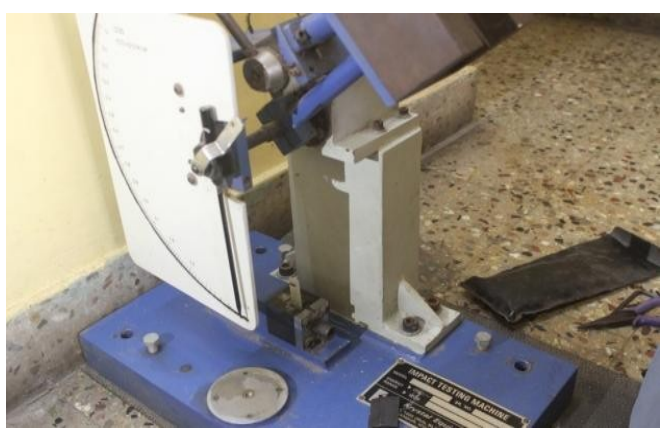

Figure 3: Impact Tester. 


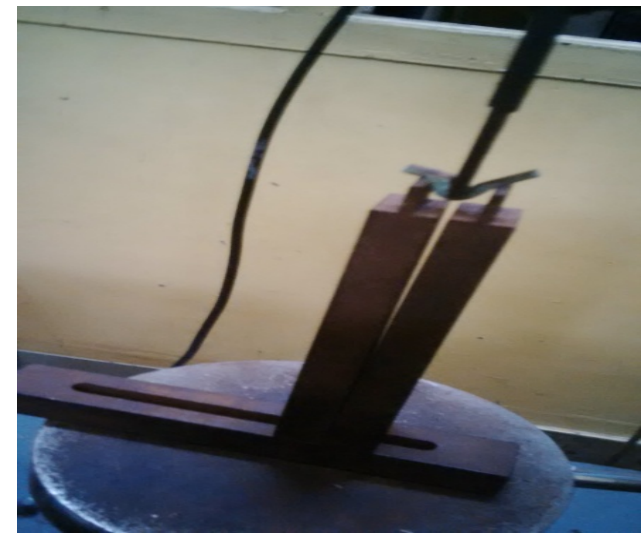

Figure 4: Typical ILLS set up.
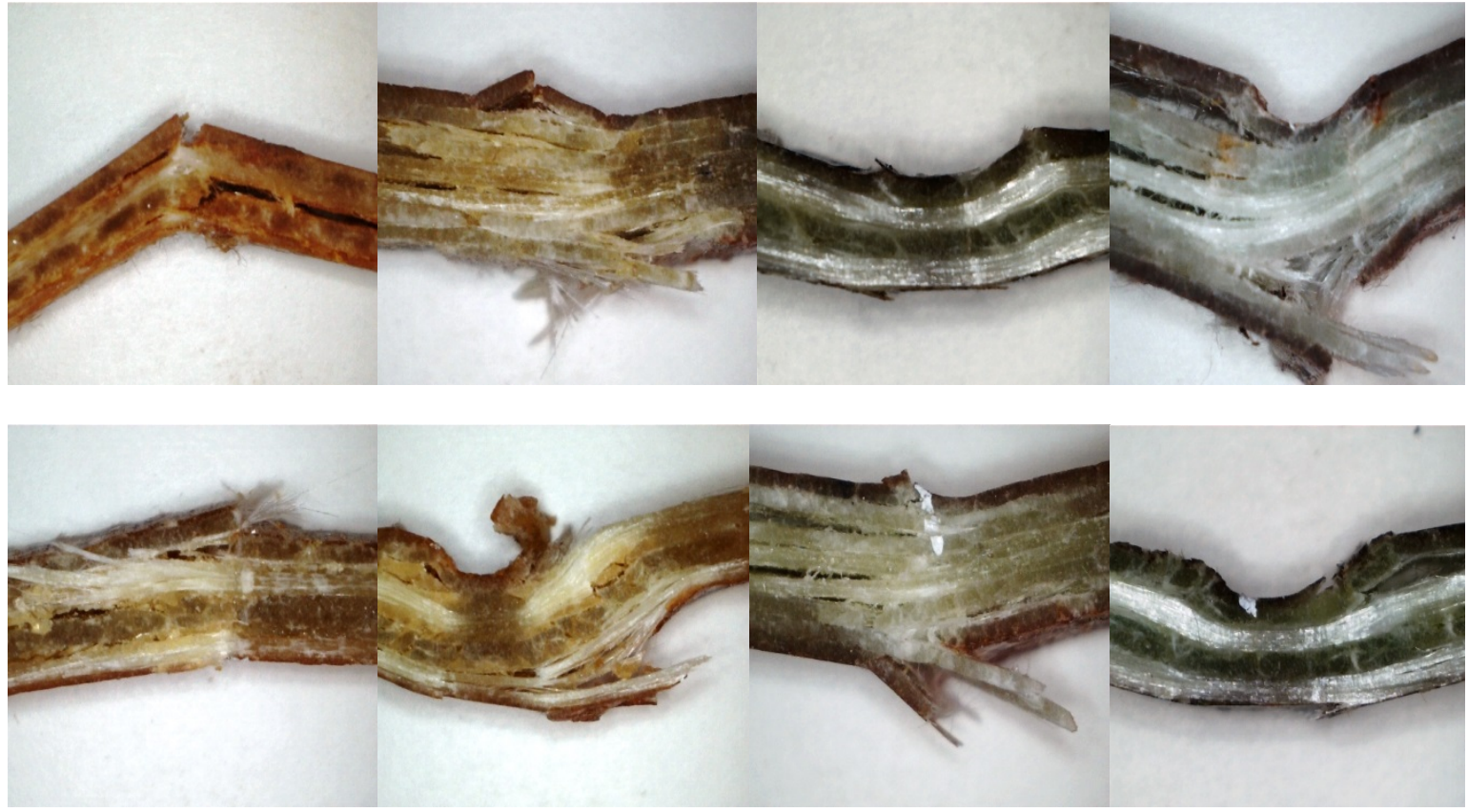

Figure 5: Some of the Tested Samples for ILS

\section{EXPERIMENTAL OBSERVATION}

Table 1: Ilss \& Impact Strength

\begin{tabular}{|l|l|l|l|l|l|}
\hline \multicolumn{1}{|c|}{ Test } & L1 & L2 & L3 & L4 & \multicolumn{1}{c|}{ Laminate Coding Description } \\
\hline $\begin{array}{l}\text { Interlaminar shear strength } \\
\text { (Mpa) }\end{array}$ & 6 & 7 & 4.4 & 11 & $\begin{array}{l}\text { Epoxy + 5\% Cyanate Blended Epoxy + 10\% Cyanate } \\
\text { Blended Epoxy + 15\% Cyanate Blended Epoxy,300 GSM, } \\
\text { Random oriented, 4 plied \& cross plied, Hand layup method, } \\
\text { Room cured }\end{array}$ \\
\cline { 1 - 5 } $\begin{array}{l}\text { Impact strength } \\
\text { (Joules) }\end{array}$ & 2.2 & 2.7 & 4.6 & 3.1 & \\
\hline
\end{tabular}

Table Ii: Ilss \& Impact Strength

\begin{tabular}{|c|c|c|c|c|c|}
\hline Test & $\mathbf{L 5}$ & L6 & L7 & L8 & Laminate Coding Description \\
\hline $\begin{array}{l}\text { Interlaminar shear strength } \\
\text { (Mpa) }\end{array}$ & 18 & 21 & 23 & 19 & Epoxy $+5 \%$ Cyanate Blended Epoxy $+10 \%$ Cyanate Blended \\
\hline $\begin{array}{l}\text { Impact strength } \\
\text { (Joules) }\end{array}$ & 3.2 & 2.7 & 4.6 & 32 & $\begin{array}{l}\text { Epoxy }+15 \% \text { Cyanate Blended Epoxy, } 400 \text { GSM, Bi } \\
\text { Directional, } 4 \text { plied \& cross plied, Hand layup method, Room }\end{array}$ \\
\hline
\end{tabular}


cured

Table 3: Ilss \& Impact Strength

\begin{tabular}{|l|c|c|c|c|c|}
\hline \multicolumn{1}{|c|}{ Test } & L9 & L10 & L11 & L12 & Coding Details Description \\
\hline $\begin{array}{l}\text { Interlaminar shear } \\
\text { strength } \\
\text { (Mpa) }\end{array}$ & 9 & 11 & 15 & 22 & $\begin{array}{c}\text { Epoxy + 5\% Cyanate Blended Epoxy + 10\% } \\
\text { Cyanate Blended Epoxy + 15\% Cyanate Blended } \\
\text { Epoxy, 410 GSM, Uni Directional, 4 plied \& cross } \\
\text { Impact strength } \\
\text { (Joules) }\end{array}$ \\
\hline
\end{tabular}

Table 4: Ilss \& Impact Strength

\begin{tabular}{|c|c|c|c|c|c|c|}
\hline Test & L13 & L14 & L15 & L16 & L17 & Laminate Coding Description \\
\hline $\begin{array}{l}\text { Interlaminar shear } \\
\text { strength } \\
\text { (Mpa) }\end{array}$ & 10 & 1.3 & 26 & 30 & 25 & \multirow{2}{*}{$\begin{array}{l}\text { Epoxy }+5 \% \text { Cyanate Blended Epoxy }+ \\
10 \% \text { Cyanate Blended Epoxy }+15 \% \\
\text { Cyanate Blended Epoxy, } 1200 \text { GSM, Uni } \\
\text { Directional, } 4 \text { plied \& cross plied, Hand } \\
\text { layup method, Room cured }\end{array}$} \\
\hline $\begin{array}{l}\text { Impact strength } \\
\text { (Joules) }\end{array}$ & 6 & 5 & 8 & 10 & 9.2 & \\
\hline
\end{tabular}

Table 5: Ilss \& Impact Strength

\begin{tabular}{|l|c|c|c|c|c|c|}
\hline \multicolumn{1}{|c|}{ Test } & L18 & L19 & L20 & L21 & L22 & Laminate Coding Description \\
\hline $\begin{array}{l}\text { Interlaminar shear } \\
\text { strength } \\
\text { (Mpa) }\end{array}$ & 22 & 30 & 34 & 34 & 26 & $\begin{array}{l}\text { Epoxy + 5\% Cyanate Blended Epoxy + } \\
10 \% \text { Cyanate Blended Epoxy + 15\% } \\
\text { Cyanate Blended Epoxy, 1200 GSM, Uni } \\
\text { Directional, 4 plied \& cross plied, Hand } \\
\text { layup method, Oven cured }\end{array}$ \\
\hline $\begin{array}{l}\text { Impact strength } \\
\text { (Joules) }\end{array}$ & 7.7 & 8.4 & 10.3 & 12 & 10.6 \\
\hline
\end{tabular}

Table 6 \& 7: Ilss \& Impact Strength for Glass Filled Cyanate Blended Epoxies

\begin{tabular}{|c|c|c|c|c|c|c|}
\hline Test & L23 & L24 & L25 & \multirow{3}{*}{\multicolumn{3}{|c|}{$\begin{array}{l}\text { Epoxy } 4 \text { plied }+15 \% \text { Epoxy cyanate blended epoxy }+0 \% \text { Glass } \\
\text { filled Cyanate Blended Epoxy }+10 \% \text { Glass filled Cyanate } \\
\text { Blended Epoxy }+20 \% \text { Glass filled Cyanate Blended Epoxy, } 30 \% \\
\text { Glass filled Cyanate blended Epoxy, } 1200 \text { GSM, Uni Directional, } 4 \\
\text { plied \& cross plied, Compression moulding, Oven cured }\end{array}$}} \\
\hline $\begin{array}{l}\text { Interlaminar } \\
\text { shear strength } \\
(\mathrm{Mpa})\end{array}$ & 79 & 55 & 39 & & & \\
\hline $\begin{array}{l}\text { Impact } \\
\text { strength } \\
\text { (Joules) }\end{array}$ & 25 & 20 & 18 & & & \\
\hline Test & L26 & $\mathbf{L 2 7}$ & L28 & $\mathbf{L 2 9}$ & $\mathbf{L 3 0}$ & Laminate Coding Description \\
\hline $\begin{array}{l}\text { Interlaminar } \\
\text { shear strength } \\
(\mathrm{Mpa})\end{array}$ & 17 & 18 & 41 & 29 & 20 & \multirow{2}{*}{$\begin{array}{l}\text { Epoxy } 4 \text { plied }+15 \% \text { Epoxy cyanate Blended } \\
\text { epoxy }+0 \% \text { Glass filled Cyanate Blended } \\
\text { Epoxy }+10 \% \text { Glass filled Cyanate Blended } \\
\text { Epoxy }+20 \% \text { Glass filled Cyanate Blended } \\
\text { Epoxy, } 30 \% \text { Glass filled Cyanate blended Epoxy, } \\
1200 \text { GSM, Uni Directional, } 3 \text { plied \& cross } \\
\text { plied, Compression moulding, Oven curing }\end{array}$} \\
\hline $\begin{array}{l}\text { Impact } \\
\text { strength } \\
\text { (Joules) }\end{array}$ & 6 & 9.3 & 19 & 15 & 14 & \\
\hline
\end{tabular}


Table 8: Ilss \& Impact Strength for Glass Filled Cyanate Blended Epoxies

\begin{tabular}{|c|c|c|c|c|}
\hline Test & L31 & L32 & L33 & Laminate Coding Description \\
\hline $\begin{array}{l}\text { Interlaminar } \\
\text { shear strength } \\
\text { (Mpa) }\end{array}$ & 76 & 53 & 17.8 & \multirow{2}{*}{$\begin{array}{l}15 \% \text { Epoxy }+3 \% \text { Glass filled Cyanate Blended Epoxy }+5 \% \\
\text { Glass filled Cyanate Blended Epoxy }+7 \% \text { Glass filled } \\
\text { Cyanate Blended Epoxy, } 1200 \text { GSM, Uni Directional, } 4 \\
\text { plied \& cross plied, Compression moulding, Oven cured }\end{array}$} \\
\hline $\begin{array}{l}\text { Impact strength } \\
\text { (Joules) }\end{array}$ & 29.2 & 23 & 15 & \\
\hline
\end{tabular}

Table 9: Ilss \& Impact Strength For Cyanate Blended Epoxies

\begin{tabular}{|c|c|c|l|}
\hline Laminate & $\begin{array}{c}\text { Inter Laminar } \\
\text { Shear Strength }\end{array}$ & $\begin{array}{c}\text { Impact } \\
\text { strength }\end{array}$ & \multicolumn{1}{|c|}{ Laminate Coding Description } \\
\hline L34 & 15 & 3 & $\begin{array}{l}15 \% \text { Cyanate Blended Epoxy, 2 Plied, Room } \\
\text { Cured, Compression Molding }\end{array}$ \\
\hline L35 & 10 & 6 & $\begin{array}{l}15 \% \text { Cyanate Blended Epoxy, 2 Plied, oven Cured, } \\
\text { Compression Molding }\end{array}$ \\
\hline L36 & 13 & 7 & $\begin{array}{l}15 \% \text { Cyanate Blended Epoxy, 3 Plied, Room } \\
\text { Cured, Compression Molding }\end{array}$ \\
\hline L37 & 15 & 10 & $\begin{array}{l}15 \% \text { Cyanate Blended Epoxy, 4 Plied, Room } \\
\text { Cured, Compression Molding }\end{array}$ \\
\hline L38 & 13 & 11 & $\begin{array}{l}15 \% \text { Cyanate Blended Epoxy, 5 Plied, Room } \\
\text { Cured, Compression Molding }\end{array}$ \\
\hline L39 & 29 & 13 & $\begin{array}{l}15 \% \text { Cyanate Blended Epoxy, 5 Plied, } \\
\text { Compression Moulding Oven Cured }\end{array}$ \\
\hline
\end{tabular}

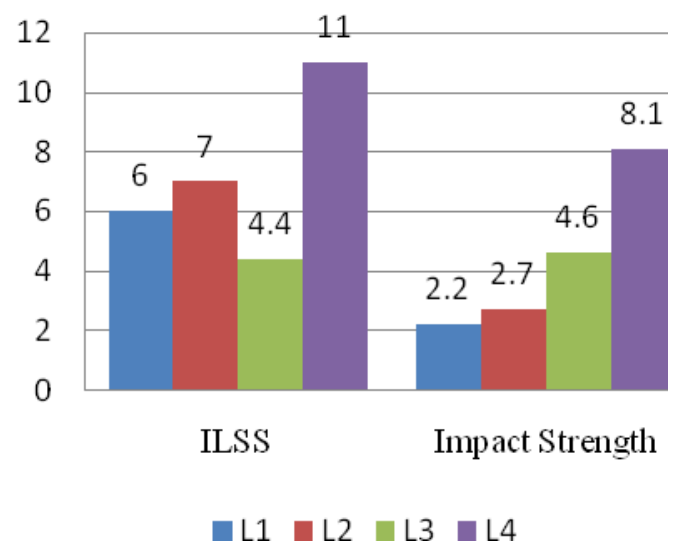

Figure 6: Comparison of ILSS (Mpa) \& Impact Strength (Joules) Epoxy +

5\% Cyanate Blended Epoxy $+10 \%$ Cyanate Blended Epoxy $+15 \%$ Cyanate Blended Epoxy,300 GSM, 


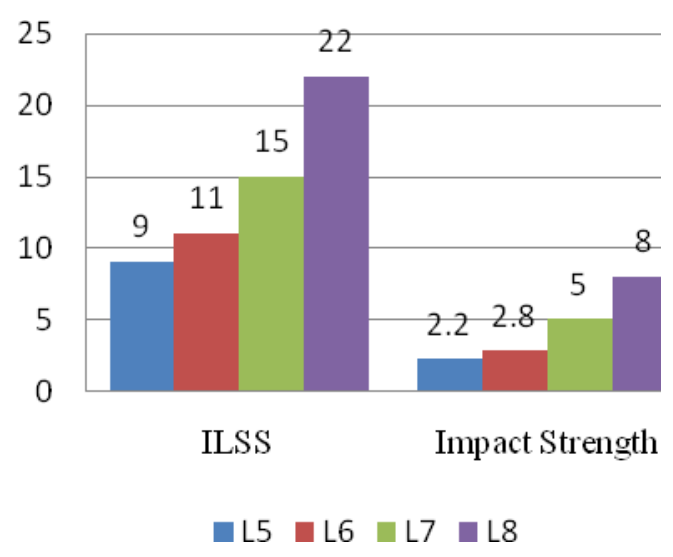

Figure 7: Comparison of ILSS (Mpa) \& Impact Strength (Joules) Epoxy +

$5 \%$ Cyanate Blended Epoxy $+10 \%$ Cyanate Blended Epoxy $+15 \%$ Cyanate Blended Epoxy, 400 GSM, Bi Directional, 4 plied \& cross plied, Hand layup method, Room Cured

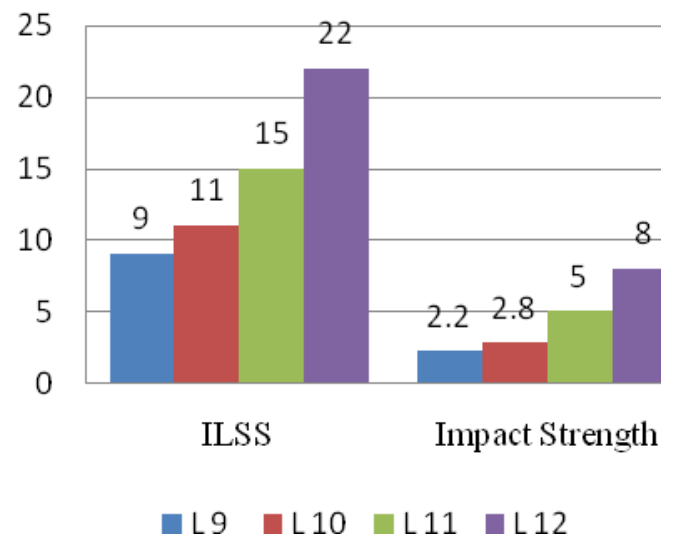

Figure 8: Comparison of ILSS (Mpa) \& Impact Strength (Joules) Epoxy

$+5 \%$ Cyanate Blended Epoxy + 10\% Cyanate Blended Epoxy + 15\% Cyanate Blended Epoxy, 410 GSM, Uni

Directional, 4 plied \& cross plied, Hand layup method, Room cured

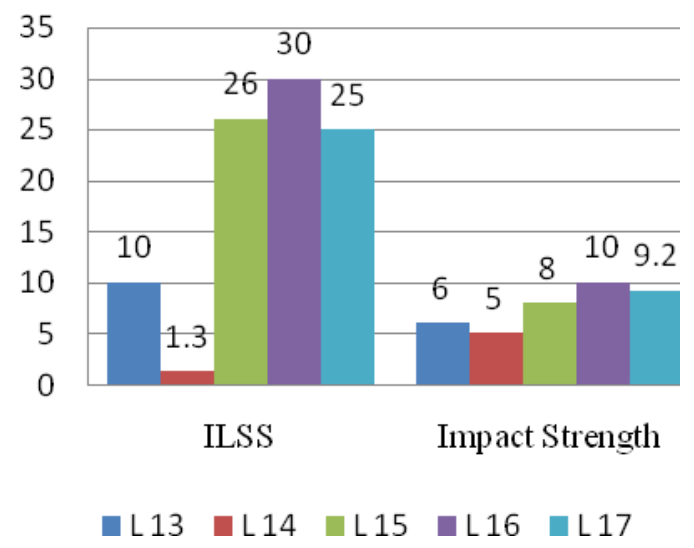

Figure 9: Comparison of ILSS (Mpa) \& Impact strength (Joules)Epoxy + 5\% Cyanate Blended Epoxy + 10\%

Cyanate Blended Epoxy + 15\% Cyanate Blended Epoxy, 1200 GSM, Uni Directional, 4 plied \& cross plied, Hand layup method, Room cured 


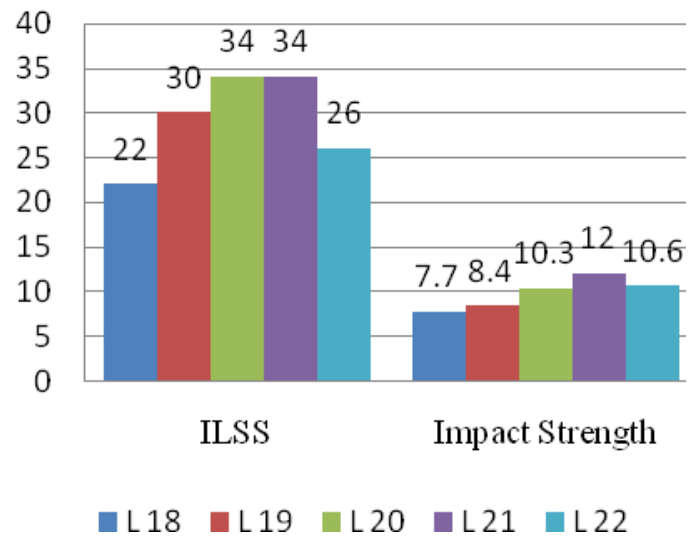

Figure 10: Comparison of ILSS (Mpa) \& Impact Strength (Joules)

Epoxy $+5 \%$ Cyanate Blended Epoxy $+10 \%$ Cyanate Blended

Epoxy $+15 \%$ Cyanate Blended Epoxy, 1200 GSM, Uni-

Directional, 4 plied \& cross plied, Hand layup method, Oven Cured

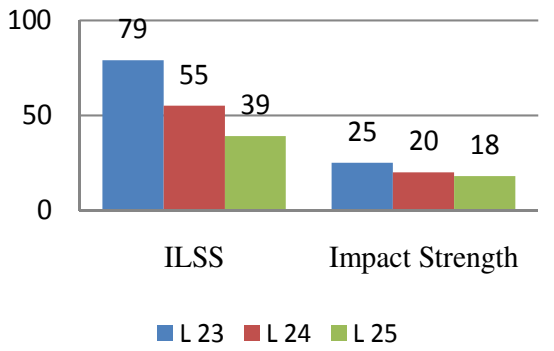

Figure 11: Comparison of ILSS (Mpa) \& Impact strength (Joules)

Epoxy 4 plied $+15 \%$ Epoxy Cyanate blended epoxy $+0 \%$ Glass filled Cyanate Blended Epoxy $+10 \%$ Glass filled Cyanate Blended Epoxy + 20\% Glass filled Cyanate Blended Epoxy, 30\% Glass filled Cyanate blended Epoxy, 1200

GSM, Uni Directional, 4 plied \& cross plied, Compression moulding, Oven cured

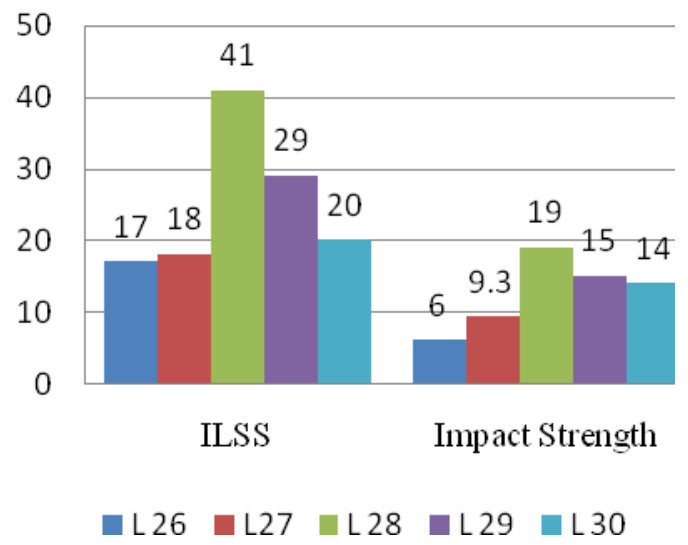

Figure 12: Comparison of ILSS (Mpa) \& Impact strength (Joules)

Epoxy 4 plied $+15 \%$ Epoxy cyanate Blended epoxy $+0 \%$ Glass filled Cyanate Blended Epoxy $+10 \%$ Glass filled Cyanate Blended Epoxy + 20\% Glass filled Cyanate Blended Epoxy, 30\% Glass filled Cyanate blended Epoxy, 1200

GSM, Uni Directional, 3 plied \& cross plied, Compression moulding, Oven cured 


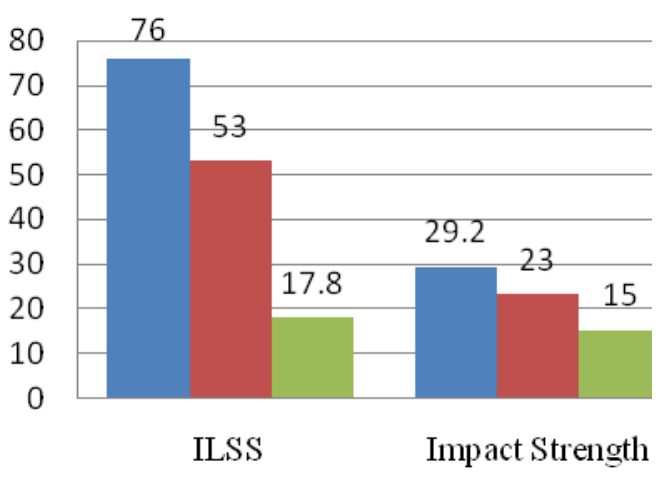

- 31 L32 L 33

Figure 13: Comparison of ILSS (Mpa) \& Impact strength (Joules)

$15 \%$ Epoxy $+3 \%$ Glass filled Cyanate Blended Epoxy $+5 \%$ Glass filled Cyanate Blended Epoxy $+7 \%$ Glass filled Cyanate Blended Epoxy, 1200 GSM, Uni Directional, 4 plied \& cross plied, Compression moulding, Oven cured

Figure 6 captures the role played by higher gsm 1200 unidirectional fiber under room curing conditions in establishing it as the better reinforcement fiber among the all other types of fibers.

Figure 7 captures the further enhancement in the value of $1200 \mathrm{gsm}$ fiber when being used under oven curing conditions

Figure 8 compares the laminate thickness and filler concentrations on the ILSS and Impact strength.

Figure 9 provides the details about the reinforcing capabilities of glass microspheres and fumed silica particles.

Figure 10 relates the significance of thinner to thicker laminates in controlling the properties.

\section{RESULTS \& DISCUSSIONS}

It was observed that the impact strength was found to be better for 4 plied hybrid laminates with 1200 gsm filled with fillers cured through oven curing. Impact strength depends on mainly matrix behavior, its adhesion tendency with respect to the matrix and to some extent the fiber surface chemistry. The addition of particulate fillers adds up to the reinforcement enabling better surface matrix interface off the principle $x-y$ plane. Weave style and fiber orientation across the section will also add up to the matrix interface strengthening. It was observed that the stiffer and tougher 4 plied oven cured laminate with a maximum impact strength of 10 Joule with an ILSS strength measured at $30 \mathrm{Mpa}$. Behaviour of the dispersed particles beyond the optimum addition was found to have a detrimental effect on the laminate structural strengths due to its influence on bringing down the net cross section besides nucleating the micro cracks in the vicinity of the debonded dispersed fillers. Better impact strength was also found out of the natural tendency of the cyante blended epoxy to get toughened out of increased cross linked density due to oven curing. Matrix Rheology is less significant in deciding ILLS than impact strength. The matrix rheological behavior in resisting the deformation could be enhanced by adding the reinforcement in terms of fillers concentration. The roles of two different types of filler here predicts the positive influence of micro spheres concentration till its optimum value of $10 \%$ at which it gains 25Joules against the impact load and in fumed silica, rather a very less concentration of $3 \%$ itself is good enough to offer an impact strength of 29.2 Joules. This is due to the thixotropic tendency of fumed silica and its inability to get cured when added in larger concentrations. The latter's better performance is owing to the agglomeration besides its grouping to pin down the cracks and the wide dispersed tendency of fumed silica in the matrix, enabling it to offer better stiffness to the matrix, under impact (1) 
The ILSS of a laminated PMC depends on matrix phase additions like fillers, the matrix mixing procedure, the glass fiber finish chemistry, and its slenderness' ratios, concentration and the matrix Rheology, though not so significant like that in impact. If the ability to improve the fiber matrix adhesion could be achieved, then the rate of transverse crack growth across the $\mathrm{z}$ plane could be reduced and further it could also bring down the possibility of failure by delamination between the plies out of debonding at the interfaces. By adding fillers off the principle plane of $x-y$ direction, matrix gets tougher by the added reinforcement and in turn they inhibit the growth of transverse cracks across the section.(1). The three ways to reduce the number of ply failures in the z-direction are to increase the resin-to-resin bond strength which is enhanced by toughening during oven curing, to increase the strength of resin to-glass interface by using 1200 gsm thick fiber with a superior fiber chemistry, and to minimize the differences in the thermal properties of the laminate by adding different fillers exhibiting different

Although a cross-ply lay-up within the laminate has been interlinear shear loaded, damage and failure could only be found within the transverse plies, as shown in the fractured images. Over their thickness, fiber/matrix-deboning proved to be pronounced near the ply boundaries of the transverse plies, where exceptionally high shear strains could be found. De bonding was found to be near the ply boundaries of Cross plies across the section with localized larger stress concentrations. (2)

Transverse crack damage was generally the first observed damage. The second type of damage was longitudinal cracking and/or delamination was found to be more in 5 plied thicker laminates, as shown in the images.(3) For these failures, the main factor appears to be the increase in stress due to the reduction in net cross-section. Failure of specimens with high levels of distributed voids was also consistent with failure being controlled mainly by the reduction in net section. It is suggested that the commonly observed decrease in inter laminar shear strength with voids is due to a combination of the reduction of cross-sectional area due to distributed voids and initiation of failure from larger discrete voids. Voids thus reduce the net section area and besides that initiate cracks from larger discrete voids. (4) Presence of blisters, de bonding and de laminations across the plies were seen in the fractured sections of the different laminates, as shown in the images. The varying pattern of failure by ILSS mode, further substantiates the prominent reason behind them, like increased void content either due to faulty filler concentrations in case of hybrid composites or because of poor interfacial bond strength between reinforcements and the matrix. The onset of de lamination and fractures was found faster in the specimens with un optimized filler concentrations (5). On the interdependence of the curing and the fillers volume fraction in influencing the toughness and hence the impact strength, an irregular response pattern was observed.(13)

\section{REFRENCES}

1. Dahsin Liu, Lawrence E. Malvern, "Matrix cracking in impacted Glass/Epoxy Plates," Journal of composite materials, vol. 21, pp. $594-609$, July 1987.

2. S.A.Hitchen, R.M.J. Kemp, "The effect of stacking sequence on impact damage in a carbon fibre/Epoxy composite," Composites, vol. 26, pp. 207 - 214, March 1995.

3. Michael R. Wisnom, Tom Renyolds, Nigel Gwilliam, "Reduction in Interlaminar shear strength by discrete and distributed voids, " Composites Science \& Technology, vol 56. pp. 93-101, 1996.

4. Jweeg, Muhsin J., and M. U. H. A. N. N. A. D. Al-Waily. "Determination of Inter-Laminar Shearing Stresses Using A Suggested Analytical Solution In The Composite Laminated Plates." International Journal of Mechanical Engineering (Ijme) 2, 5, Nov 2013, 45-60 
5. Denis Daniel Cartie, "Effect of resin and fibre properties on impact and compression after impact performance of CFRP," Composites part A Applied science and manufacturing, vol. 33, pp. 483 - 493, April 2002.

6. B.Z.Jang, L.C.Chen, C.Z.Wang, H.T.Lin, R.H.Zee, "Impact resistance and energy absorption mechanisms in hybrid composites," Composites science and technology, vol. 34, pp. 305 - 335, February 2003.

7. Ismail, Mahmud Rasheed, Z. A. A. Ali, and Muhannad Al-Waily. "Delamination Damage Effect on Buckling Behavior of Woven Reinforcement Composite Materials Plate." International Journal of Mechanical \& Mechatronics Engineering IJMME-IJENS 18.05 (2018): 83-93.

8. W.J. Cantwell, J Morton, “The impact Resistance of composite materials - A Review," Composites, vol.22, pp. 347 - 362, April 2003.

9. Dahsin Liu, "Characterization of Impact Properties and Damage Process of Glass/Epoxy Composite Laminates," SAGE Journals, vol. 38, pp. 1425 - 1442, August 2004.

10. Serge Abrate, “Impact on laminated Composite Materials - A Review,” The American Society of Mechanical Engineers Applied Mechanics Reviews, vol 44, pp.155 -190, April 2009.

11. Resan, Kadhim K., et al. "Influence of Temperature on Fatigue Life for Friction Stir Welding of Aluminum Alloy Materials." International Journal of Mechanical \& Mechatronics Engineering IJMME-IJENS 18.02 (2018).

12. Zhan - Sheng Guo, Ling liu, Bo-Ming Zhang, Shanyi Du. "Critical void content for thermoset composite laminates.” Journal of Composite Materials, vol. 43, pp. 1775 - 1790, August 2009.

13. Stephan Hinz, Toshihiro Omoori, Masaki Hojo, Karl Schulte, "Damage characterization of fibre metal laminates under interlaminar shear load,” Composites Part A: Applied Science and Manufacturing, vol. 40, pp. 925-931, 2009.

14. Suman, Swapnil, et al. "Influence of functionalized multi-walled carbon nanotubes On the mechanical properties and delamination in drilling of CFRP composites." International Journal of Mechanical and Production Engineering Research and Development 8.3 (2018): 1067-1084.

15. George B.Piotrouski, marty chote, and Scott Lucas, "The Effect of Processing, Glass Finish, and Rheology on the Interlaminar Shear Strength of a Woven e-Glass Reinforced Polymer Matrix Composite," Isola, August 2016.

16. Sandeep agarwal, Kalyan Kumar Singh, PK Sarkar, "Impact Damage on Fibre - Reinforced polymer matrix composite - A Review,” Journal of Composite Materials, vol. 48, pp. 317 - 332, February 2014

17. Jean-Luc Rebiere, “Matrix cracking and delamination evolution in composite cross-ply laminates," Cogent Engineering Mechanical Engineering Research article, 2014.

\section{AUTHOR'S PROFILE}

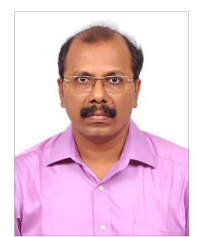

W.ANDREW NALLAYAN is a Research scholar at St. Peters Institute of Higher Education and Research, and works as a faculty in Dr. MGR Educational and Research Institute, Chennai, India. His area of interest is composite materials and Physical Metallurgy. He completed his Masters in Manufacturing Technology at REC, Trichy in December 1993. He has 
more than 28 years teaching experience. He has published 5 papers in journals of repute. He is currently working on Hybrid composites for thin walled Radomes. He can be reached at

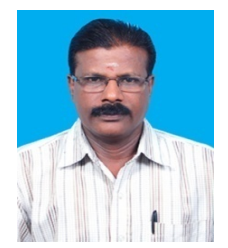

Dr. K. GURUSAMI, is an Associate Professor and also the Project manager at Technology Business Incubation cell at St. Peters Institute of Higher Education and Research, Chennai, India. He has completed his Doctorate from Anna University and also holds a MBA degree from University of Madras. He has around 20 years of Industrial experience and 14 years of teaching experience to his credit .He possess ASNT certificate and Has undergone advanced proficiency training in "Welding Technology for Supervisors and Engineers". His main areas of interest include Laser Shock Peening and Surface Modification of Metals, Lean Manufacturing and NDT in Manufacturing Industries. He published 16 International journals and many were in National journals. He is associated with Henry Giessen bier Fellowship and in 1995, he was awarded with Outstanding Young Person for Meritorious Service to the Humanity. His mail id is dr.gurusami @ stpetersuniversity.org

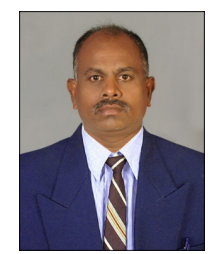

Dr. K. R. Vijaya Kumar, working as Professor in Department of Mechanical Engineering at Dr. MGR Educational and Research Institute, Tamil Nadu, India. He did his Ph.D in Composite Materials at Anna University in the year 2011. He did his M.E (Engineering Design) at Anna University in the year 2001 and B.E (Mechanical Engineering) from Bharathi University in the year 1993. He has published more than 30 articles in various reputed journals. He has guided 4 Ph.D 's. He successfully completed three defense funded projects as co-investigator. His areas of specialization is composites materials, nano technology and engineering design. 

